\title{
A Test for the Rational Ignorance Hypothesis: Evidence from a Natural Experiment in Brazil ${ }^{*}$
}

\author{
Fernanda L L de Leon ${ }^{\dagger}$ \\ University of East Anglia
}

Renata Rizzi ${ }^{\ddagger}$

Universidade de São Paulo

November 5, 2013

\begin{abstract}
This paper tests the rational ignorance hypothesis by Downs (1957). This theory predicts that people do not acquire costly information to educate their votes. We provide new estimates for the effect of voting participation by exploring the Brazilian dual voting system - voluntary and compulsory - whose exposure is determined by citizens' date of birth. Using a fuzzy RD approach and data from a self-collected survey, we find no impact of voting on individuals' political knowledge or information consumption. Our results corroborate Downs's predictions and refute the conjecture by Lijphart (1997) that compulsory voting stimulates civic education.
\end{abstract}

*We are grateful to Alan Auerbach and two anonymous referees for many constructive suggestions.We also thank Thushyanthan Baskaran, Dan Benjamin, Stephen Coate, Gianmarco Leon, Carlos Eduardo Goncalves, Naercio Menezes, Jeffrey Prince, Bernardo Silveira and participants of Lisbon Political Economy Meeting, Lacea Political Economy Group Meeting and Silvaplana Political Economy Workshop for helpful comments. We are very gratful to Ernesto Birner and many other teachers at Anglo Vestibulares, Escola E. Professor Ascendino Reis, Escola E. Rui Bloem, Escola E. Professor Leopoldo Santana and Universidade de São Paulo for their support and help in the application of our survey. We thank Insper Institute for their financial support.

${ }^{\dagger}$ Assistant Professor. School of Economics. University of East Anglia. E-mail: f.de-leon@uea.ac.uk

${ }^{\ddagger}$ Ph.D. Department of Economics. Universidade de São Paulo. E-mail: rrizzi@usp.br 


\section{Introduction}

It is a well documented fact that the American electorate is poorly informed about politics. As Delli Carpini and Keeter (1996) remark, during the 1992 US Election, only $15 \%$ of voters knew that George Bush and Dan Quayle (Republican candidates at that time) favored the death penalty, and only $5 \%$ knew that these candidates had proposed cuts in the capital gains tax. Similarly, in a recent survey, nearly half of the respondents incorrectly affirmed that the Troubled Asset Relief Program was signed into law by President Barack Obama (Pew Research Center, 2010).

This feature of the constituency is in line with predictions of the rational voters' theory and with the "rational ignorance" hypothesis proposed by Downs (1957). Voters recognize that, in large elections, their ballots have a vanishingly small chance of being decisive. Therefore, regardless of how much they may care about election results, they dedicate little or no effort to acquire information to make educated votes. This result is central in political economy. Yet it is striking and at odds with predictions from recent alternative theories of voting behavior (Feddersen and Sandroni 2006a, Degan 2006).

To provide an answer for whether people acquire information to vote, and a result for the dispute above, we explore the Brazilian dual voting legislation. Those who are between 16 and 18 years old are entitled (but not obliged) to vote, while those older than 18 are legally required to turn out. ${ }^{1}$ This legislation provides an exogenous shift in an individual's likelihood to vote, which is used to identify the causal effects. We explore the discontinuity in voting participation at the age of eighteen to test if individuals become more knowledgeable once they must vote. The data comes from a survey we conducted on the week following the 2010 Presidential Election. We collected information from 5,562 individuals with ages near the threshold determining the transition from voluntary to compulsory voting legislation.

This paper makes two important contributions. First, we test the validity of the rational ignorance hypothesis. In doing so, our analysis offers significant advantages with respect to many other studies on the voting effects on real-life elections. ${ }^{2}$ Our data was collected just a few days after the election. Hence, we are able to access individuals' knowledge and information levels as they prepare to vote. Also, our identification strategy is quite compelling, as the compulsory legislation provides a powerful instrument which we use in our IV analysis outlined in Section III. Turnout in our sample is close to $30-60 \%$ higher among individuals "just exposed" to compulsory voting then

\footnotetext{
${ }^{1}$ The voting enforcement mechanism is explained in Section II.A.

${ }^{2}$ For excellent reviews, see Michelson and Nickerson (2011) and Merlo (2006.)
} 
among those "just about to" be included under this system. Worth mentioning is that aggregated turnout rates in our data are very much in line with those observed for the Brazilian population.

To our knowledge, this paper is the first to estimate the contemporaneous effects of voting participation on political knowledge and information acquisition using data from a large-scale election under real-world incentives. Moreover, by exploiting the dual voting system, this paper contributes to the discussion about the merits of the compulsory electoral system, currently in place in $14 \%$ of countries. An important argument in favor of this policy is that it entices the population to be more politically engaged, as advocated by Lijphart (1997). Our second contribution is the evaluation of this point. ${ }^{3}$

It is clear, from the RD graphical analysis, that the increase in turnout, as a consequence of the compulsory voting legislation, is not followed by an increase in political knowledge among the population. This supports our IV results, which show no statistically significant effect of voting participation on making individuals more knowledgeable and more likely to acquire information. These findings are robust to various econometric specifications and different measures of information acquisition. Furthermore, we find no differences by race, gender, mother's education and mother's political affiliation, demonstrating that heterogeneous effects by groups with arguably different incentives to acquire information are not masking any voting effect.

Our results show that, at least for the forced voters, which in Brazil are more than a third of the number of voluntary voters, the consumption of political information comes from reasons other than getting ready to vote (e.g. interest in politics, having informal discussions with friends). This finding is in line with Downs's (1957) hypothesis and with predictions from economic models of strategic voting (Martinelli 2006, 2007).

It is a well documented fact that the American electorate is poorly informed about politics. As Delli Carpini and Keeter (1996) remark, during the 1992 US Election, only $15 \%$ of voters knew that George Bush and Dan Quayle (Republican candidates at that time) favored the death penalty, and only $5 \%$ knew that these candidates had proposed cuts in the capital gains tax. Similarly, in a recent survey, nearly half of the respondents incorrectly affirmed that the Troubled Asset Relief Program was signed into law by President Barack Obama (Pew Research Center, 2010).

This feature of the constituency is in line with predictions of the rational voters' theory and with the "rational ignorance" hypothesis proposed by Downs (1957). Voters

\footnotetext{
${ }^{3} \mathrm{~A}$ different part of the literature uses a game theory framework to analyze voting systems from a welfare perspective (Borgers 2004; Krasa and Polborn 2005; Krishna and Morgan 2011). 
recognize that, in large elections, their ballots have a vanishingly small chance of being decisive. Therefore, regardless of how much they may care about election results, they dedicate little or no effort to acquire information to make educated votes. This result is central in political economy. Yet it is striking and at odds with predictions from recent alternative theories of voting behavior (Feddersen and Sandroni 2006a, Degan 2006).

To provide an answer for whether people acquire information to vote, and a result for the dispute above, we explore the Brazilian dual voting legislation. Those who are between 16 and 18 years old are entitled (but not obliged) to vote, while those older than 18 are legally required to turn out. ${ }^{4}$ This legislation provides an exogenous shift in an individual's likelihood to vote, which is used to identify the causal effects. We explore the discontinuity in voting participation at the age of eighteen to test if individuals become more knowledgeable once they must vote. The data comes from a survey we conducted on the week following the 2010 Presidential Election. We collected information from 5,562 individuals with ages near the threshold determining the transition from voluntary to compulsory voting legislation.

This paper makes two important contributions. First, we test the validity of the rational ignorance hypothesis. In doing so, our analysis offers significant advantages with respect to many other studies on the voting effects on real-life elections. ${ }^{5}$ Our data was collected just a few days after the election. Hence, we are able to access individuals' knowledge and information levels as they prepare to vote. Also, our identification strategy is quite compelling, as the compulsory legislation provides a powerful instrument which we use in our IV analysis outlined in Section III. Turnout in our sample is close to 30-60\% higher among individuals "just exposed" to compulsory voting then among those "just about to" be included under this system. Worth mentioning is that aggregated turnout rates in our data are very much in line with those observed for the Brazilian population.

To our knowledge, this paper is the first to estimate the contemporaneous effects of voting participation on political knowledge and information acquisition using data from a large-scale election under real-world incentives. Moreover, by exploiting the dual voting system, this paper contributes to the discussion about the merits of the compulsory electoral system, currently in place in $14 \%$ of countries. An important argument in favor of this policy is that it entices the population to be more politically engaged, as advocated by Lijphart (1997). Our second contribution is the evaluation

\footnotetext{
${ }^{4}$ The voting enforcement mechanism is explained in Section II.A.

${ }^{5}$ For excellent reviews, see Michelson and Nickerson (2011) and Merlo (2006.)
} 
of this point. ${ }^{6}$

It is clear, from the RD graphical analysis, that the increase in turnout, as a consequence of the compulsory voting legislation, is not followed by an increase in political knowledge among the population. This supports our IV results, which show no statistically significant effect of voting participation on making individuals more knowledgeable and more likely to acquire information. These findings are robust to various econometric specifications and different measures of information acquisition. Furthermore, we find no differences by race, gender, mother's education and mother's political affiliation, demonstrating that heterogeneous effects by groups with arguably different incentives to acquire information are not masking any voting effect.

Our results show that, at least for the forced voters, which in Brazil are more than a third of the number of voluntary voters, the consumption of political information comes from reasons other than getting ready to vote (e.g. interest in politics, having informal discussions with friends). This finding is in line with Downs's (1957) hypothesis and with predictions from economic models of strategic voting (Martinelli 2006, 2007).

This paper proceeds in six sections. In Section 2, we explain the rational ignorance hypothesis, competing theories and our contribution with respect to previous empirical work. In Section 3, we describe Brazilian electoral institutions and the data. In Section 4, we discuss our empirical strategy. We present the results in Section 5 and conclude in Section 6.

\section{Rational Ignorance Hypothesis and Evidence}

The rational ignorance hypothesis was formulated by Anthony Downs in 1957 in his seminal work, "An Economic Theory of Democracy." The reasoning develops as follows. Voters are uncertain about candidates and face a cost for acquiring information to help them to make a better voting decision. A rational voter knows that, in a large election, the chance that his vote will make a difference (or be pivotal) is practically zero, hence it is pointless to acquire information. Cesar Martinelli (2006, 2007) formalizes this argument using a game theoretical framework and confirms Downs's hypothesis. The optimal level of information is (negligibly) positive only if the marginal cost of acquiring information is arbitrarily small.

This result is contested by Feddersen and Sandroni (2006a) and Degan (2006), using

\footnotetext{
${ }^{6} \mathrm{~A}$ different part of the literature uses a game theory framework to analyze voting systems from a welfare perspective (Borgers 2004; Krasa and Polborn 2005; Krishna and Morgan 2011).
} 
strategic and non-strategic voting models, respectively, and departing from a pivotal vote assumption. ${ }^{7}$ Both models assume costly voting. Among the first category, ethical models suppose that individuals have preferences for candidates, and these determine which group they belong to. They participate in elections to "do their part", by following a voting rule that maximizes their group's aggregate utility if everybody followed it (Coate and Conlin 2004; Feddersen and Sandroni 2006b.) ${ }^{8}$ Building on this framework, Feddersen and Sandroni (2006a) develop a model in which individuals can acquire costly information to vote. They assume two types of voters: independents, who are uncertain about their preferred candidate and hence can benefit from information, and partisans, who always prefer one of two candidates. Similar to Feddersen and Pesendorfer (1996), in their model, Feddersen and Sandroni (2006a) demonstrate that some independents will vote to balance out any partisan advantage. In a situation with no uncertainty about this advantage, they show that almost no information acquisition occurs; only a minimum group of informed independents is needed to favourably decide the election. However, if voters are uncertain about the magnitude of the partisan difference, independents will choose to acquire information (because they cannot precisely anticipate the proportion of uninformed voters needed to balance out a partisan advantage and elect their preferred candidate at minimum costs).

Other models assume that people vote due to intrinsic motivations (e.g. civic duty), but decide independently from others and regardless of whether their votes are decisive (Degan and Merlo 2011; Matsusaka 1995). Degan (2006) explains the process of information acquisition and voting turnout in a setting in which individuals face uncertainty about candidates' policy positions, and assuming that citizens compare the exogenous and intrinsic benefit of voting to the cost of making a mistake (i.e. of voting for someone that may not be the preferred candidate). This cost in turn can be attenuated with costly information acquisition. ${ }^{9}$ Degan's model also predicts heterogeneous effects: middle-of-the-road or independents are more likely to acquire information than partisans are. This is because partisans are less likely to make an uninformed mis-

\footnotetext{
${ }^{7}$ The pivotal conjecture is, by no means, obvious. No large election in American history has been decided by one single vote, and still millions of citizens do turn out to vote. At least in part, this fact motivated other non-pivotal vote models, and they prove to be a good representation of turnout reality (Coate and Conlin 2004; Shachar and Nalebuff 1999, Degan and Merlo 2011; Battaglini, Morton and Palfrey 2008).

${ }^{8}$ In Feddersen and Sandroni (2006b), a rule defines a cut-off point as such that individuals with voting costs below this threshold should vote for their preferred candidate.

${ }^{9}$ Degan and Merlo (2011) interpret this cost as a psychological discomfort faced with the possibility of making a mistake, like self-blame for perhaps making an unwise voting choice.
} 
take (e.g. a left-wing person is less likely than a moderate to vote erroneously for a Democrat).

From the empirical perspective, the question of whether people acquire information in order to vote is unsettled. No doubt, that is at least partially due to the difficulty to (randomly) allocate people to the conditions of "voters" and "non-voters". 10 Similarly to this study, some previous works look at the relationship between compulsory voting and information. The evidence is mixed; some find a positive correlation based on cross-country comparisons (Gordon and Segura 1997, Berggren 2001). In conducting elections in the laboratory, Seebauer and Grober (2013) find that participants become significantly more likely to acquire costly information when assigned to compulsory elections than to voluntary ones. On the other hand, in a field experiment from Canada, Loewen, Milner and Hicks (2008), no association is found. They requested that a group of participants vote in order to receive a monetary reward, and they find no statistically significant effect of their intervention on individuals' media consumption or political knowledge.

Although relevant, these studies face important limitations in testing the rational ignorance hypothesis. Elections conducted in the lab involve few participants (3 to 7 ), failing to account for the realism of large elections (e.g. a negligible chance of a single vote determining the election result). Cross-country comparisons may carry biases due to correlations between electoral system and electorate preferences (e.g. differences in political culture or politicians running for office), and field experiments have a limited impact in inducing voting participation and hence in testing this hypothesis. ${ }^{11}$ Using data on real-life elections, within a country and an RD approach, we are able to quantify

\footnotetext{
${ }^{10}$ Main identification strategies include field-experiments inducing voting participation (in many studies by Alan Gerber, Donald Green and co-authors), comparisons across individuals based on voting eligibility status or across individuals assigned to different voting systems. The latter category, as discussed above, investigates the association between exposure to compulsory voting legislation and political information. Studies in the other categories estimate a voting effect on other political behaviors, such as political preferences (Gerber, Huber and Washington 2010, Mullainathan and Washington 2009; Meredith 2009; Elinder 2012), future voting participation (Gerber, Green and Shachar 2003) and peer's voting behavior (Nickerson 2008). Among those, the closest paper to ours is Gerber, Huber and Washington (2010). They also look at contemporaneous effects and use an instrumental variable approach, but to estimate effects of polarization (triggered by information provided in their intervention) on individuals' political views. A distinct part of the literature estimates structural models, assuming that voters have incomplete information about candidates, to explain the association between voting abstention and information (Degan 2007, Degan and Merlo 2011).

${ }^{11}$ Loewen, Milner and Hicks (2008) did not find a statistically significant effect on the payment to vote (approximately 25 dollars) in making participants more likely to vote.
} 
a voting effect by making comparisons amongst individuals who face the same politicians and environment and presumably differ only by their day of birth.

\section{Background and Data}

\subsection{Brazilian Electoral System}

Mandatory voting was introduced in Brazil in 1932, when the country's first Electoral Code was created after the Revolution of 1930. The electoral legislation was subsequently changed several times throughout the politically turbulent period that followed until 1988. ${ }^{12}$ In that year, the current Brazilian Constitution was promulgated, adopting compulsory voting for literate individuals between 18 and 69 years old and voluntary voting for citizens who are illiterate, 70 years or older, or between 16 and 18 years old (Tribunal Superior Eleitoral, TSE).

Democratic elections are currently held every second year in Brazil. All voters must register; when individuals who are required to vote fail to do so and fail to provide justification to the electoral authority, they must pay a small fine. ${ }^{13}$ Stronger sanctions are applied to those who fail to justify their absence for three consecutive elections; they are not allowed to issue or renew their passports and national identity cards and also become ineligible for public education, public jobs, cash transfer programs and credit by financial institutions maintained by the government. The legal requirement refers to showing up at the polls and the option of providing a justification for failing to vote is available, but not commonly used. According to records from the TSE, in the 2010 Presidential Elections, $82 \%$ of the total electorate opted to turn up at the polls. ${ }^{14}$

Official records only give information about voting turnout at the aggregate level. An analysis like this one demands a survey collection. This took place just after the first round of the 2010 Presidential Elections. At that time, there were three main candidates running for election: Jose Serra, Marina Silva and Dilma Rousseff.

\footnotetext{
${ }^{12}$ www.tse.jus.br/internet/ingles/historia_eleicoes/eleicoes_brasil.htm

${ }^{13}$ In 2011 , the fee was between $\mathrm{R} \$ 1.06$ (US $\$ 0.66$ ) and $\mathrm{R} \$ 3.51$ (US\$2.19), which is equivalent to $0.29 \%$ of the average monthly income in the country, according to IBGE, Population Census 2010.

${ }^{14}$ This includes Brazilians living abroad or in cities other than the one in which they are registered. Brazilians are only allowed to vote in person. According to TSE, 40.78\% of Brazil's residents who justified their absence in the 2006 Election were living in different states from where they were registered to vote.
} 


\subsection{Data}

To exploit the dual voting system, we conducted our survey aiming to interview individuals near the threshold of 18 years old. We surveyed 5,562 students in 109 classrooms from October 4-7, 2010. Since the data collection occurred immediately after Election Day (October 3), we believe responses effectively reflect outcomes in preparation to vote.

The same procedure was applied across all classrooms: an interviewer entered the room about 15 minutes before the end of a class, read an introductory script, and distributed the survey to all students. ${ }^{15}$ The survey consisted of a comprehensive set of questions about demographics, vote, media consumption and a political quiz to evaluate respondents' levels of political knowledge. In the paper, we use all outcomes related to information acquisition available in our survey. A list and description of all variables used and the political quiz are in the Web Appendix.

Respondents were told they were allowed to skip any question, but the vast majority responded to most questions and declared to have answered the survey in a serious manner. ${ }^{16}$ These high rates of participation and the quality of response are probably a result from the teachers' request for collaboration.

The sample includes students in three types of institutions: public high schools, a preparatory school for college admission and a large university, all in the city of São Paulo, Brazil. ${ }^{17}$ The first subsample includes seniors from three public schools: Escola Estadual Professor Ascendino Reis, Escola Estadual Rui Bloem and Escola Estadual Professor Leopoldo Santana. The second is composed of students taking a preparatory course for college admission exams at Anglo Vestibulares. These are mostly high school seniors or students who recently finished high school but have not yet been admitted into college. The last subsample consists of freshmen from Universidade de São Paulo

\footnotetext{
${ }^{15}$ Four types of questionnaires, containing exactly the same questions but in different orders, were randomly distributed to students in order to prevent cheating. Participants were not informed about the precise purpose of the survey, which was entitled, "Young Adults' Political Behavior," and associated with the Universidade de São Paulo (USP).

${ }^{16}$ More precisely, $93 \%$ of them declared to have answered the survey in a serious manner, and $80.25 \%$ of participants answered more than $80 \%$ of the questions. Another indication that subjects were incentivized included the facts that only $2.36 \%$ of participants abstained from answering open questions from the political quiz. Also, only $1.26 \%$ of the students abstained from answering the voting-sensitive question (whether they had voted and for whom). Merely $0.27 \%$ chose the unrevealing alternative "I do not know" as opposed to stating a vote choice.

${ }^{17}$ São Paulo is the largest metropolis in Brazil and among the cities with the highest income per capita in the country.
} 
(USP). Anglo and USP students are older and more affluent than public high school students. These differences are relevant, leading to a correlation between age and socioeconomic characteristics in the pooled sample. For this reason, our analysis is conducted exploring variation within schools.

Our analysis is mostly focused on 3,236 students who are close enough to the cutoff. These are individuals between 16.75 and 19.25 years old (i.e. within more or less 15 months from the threshold by the 2010 Election Day). ${ }^{18}$ Table A1 in the Web Appendix describes the socioeconomic characteristics and outcomes of this sample. Approximately $77 \%$ are white, and $59 \%$ are females. Most of them live with their parents $(86 \%)$ and have a mother with some college education (67\%). Sixty seven percent are Anglo students. Twenty one percent are public schools students and eleven percent are college (USP) students.

In terms of voting participation, approximately $72 \%$ of them declared to have voted in the 2010 Election. Voter over-reporting is a recognized issue in surveys (Anderson and Silver 1986). To investigate whether it is present in our data, we compare self-reported turnout in our sample and official rates in the country in Table 1. The resemblance is much closer than typically reported in international surveys in the US or the UK. ${ }^{19}$

\begin{tabular}{ccc}
\multicolumn{3}{c}{ Table 1: Turnout - Brazil } \\
\hline & & Turnout $\%$ \\
\hline Group Age & Brazil & Sample \\
16 & 23.72 & 17.64 \\
17 & 42.52 & 39.51 \\
18 to 20 & 87.28 & 87.30 \\
\hline
\end{tabular}

Note: Brazil's turnout is from TSE and IBGE

For the sake of our exercise, we are especially concerned with ruling out that vote

\footnotetext{
${ }^{18}$ The average characteristics from the whole sample are very similar to the restricted sample, except for age. In the unrestricted data, there is an unbalanced larger number of observations among the population older than 18 .

${ }^{19}$ Swaddle and Heath (1989) find that reported turnout in the 1987 British General Election Study was 10 percentage points higher than the official rate. Anderson and Silver (1986) report that, from 1964 to 1980, the fraction of respondents in the National Election Studies that reported to vote when they actually did not varied between 10 and $23 \%$. 10
} 
over-reporting occurs around the 18-year cutoff or that it happens disproportionally on the right side of the cutoff. Overall, students in our sample are quite aware of their voting requirement status, as shown in Table A1, and they may feel more uneasy about declaring abstention if they know they have to vote. This could affect our conclusions, leading to a false inference of null voting effects (since a change in behavior is not expected unless a real change in voting participation occurs). We find evidence for this subsample in line with the fact that students are being sincere about their vote responses. The results are reported in Table A2 in the Web Appendix. They show consistency between participants' voting responses and the retrospective reported turnout of their older peers. ${ }^{20}$ Furthermore, none of our results change when we conduct the analysis using reported registration status instead of participation.

\section{Empirical Strategy and Threats to Identification}

We test the prediction that voting participation does not make people more likely to acquire information and become more knowledgeable about politics. To identify voting effects, we perform instrumental variable regressions using the discontinuity generated by the exposure to the compulsory electoral system as an instrument for voting participation. This corresponds to a Fuzzy RD design. We estimate the following equations:

$$
\text { First Stage: Vote } \text { Turnout }_{i}=\eta_{0}+\gamma_{1} 1(\text { age }>18)+H(\text { age })+\beta X_{i}+\theta+\varpi_{i}
$$

$$
\text { Second Stage: } \mathrm{y}_{i}=\nu_{0}+\gamma_{2}{\text { Vote } \text { Turnout }_{i}+H(\text { age })}+\lambda X_{i}+\theta+\epsilon_{i}
$$

\footnotetext{
${ }^{20}$ More specifically, to evaluate the possibility of vote over-reporting near the cutoff, we compared "current turnout" rates (calculated based on self-reported vote in the 2010 Election by participants born in 1992 and 1993; i.e. close to the 18-year cutoff in 2010) to "retrospective turnout" rates (calculated based on self-reported vote in the 2006 election by participants born in 1988 and 1989, i.e. close to the 18-year cutoff in 2006). We conjecture that the voting question is more sensitive and likely to be misreported when it refers to the current election than to a retrospective one, for which the obligation to vote is not necessarily recalled or evident. Using this intuition, we assume that retrospective declared turnout is a proxy for the "truthful current one." As shown in Table A2 in the Web Appendix, reported turnout rates for the 2010 and 2006 cohorts are very similar, and a difference in means test does not reject the equality between them. For example, the average selfreported turnout rate amongst those who turned 18 within 7 months before the 2010 Election Day was 86.63\%, compared to $83.33 \%$ for the 2006 cohort. Amongst those who turned 18 within 7 months after the 2010 Election Day, the average self-reported turnout rate was of $43.96 \%$, compared to $46.21 \%$ for the 2006 cohort.
} 
In these equations, $Y_{i}$ represents the outcome of individual $i, X_{i}$ contains a number of covariates, $\theta$ are school fixed effects ${ }^{21}$, 1(age $\left.>18\right)$ is a dummy indicating whether the student had turned 18 by the 2010 election, $H$ (age) is a lower order polynomial in age (measured by the distance in days to the 18th birthday) that is flexible on each side of the cutoff, and $\varpi_{i}$ and $\epsilon_{i}$ are error terms.

Before presenting the results, we discuss the validity of this approach. We assume that, conditional on age, the instrument is not correlated with students' characteristics that could independently influence their political outcome. This assumption cannot be entirely verifiable; however, it can easily be rejected. As discussed by Lee and Lemieux (2010), a simple test is to fit regressions for possible confounding variables and test for jumps at the age of 18. We estimate (3) using several covariates, such as demographic characteristics $\left(X_{i}\right)$, as the endogenous variable.

$$
X_{i}=\rho_{0}+H(\text { age })+\alpha 1(\text { age }>18)+\theta+u_{i}
$$

Table 2 shows the results. Coefficients are not statistically significant for most of the variables, including demographics and family characteristics. ${ }^{22}$ One relevant exception is previous voting experience. The 2010 election was the first opportunity for all respondents in this sample to vote in a presidential election; nonetheless, participants older than 18 had the opportunity to vote in the 2008 local elections. The predicted fraction of second-time voters on the right side of the threshold is between 4-6 percentage points higher than on its left side. Considering that local elections do not receive as much attention as presidential ones and that the fraction of second-time voters is small in comparison to the change in turnout (approximately 1/5) instills confidence that this is not a relevant confounding factor. In addition, in our main analysis, we conduct regressions controlling for this characteristic.

\section{Table 2}

Another potential threat lies in the fact that effects are identified at the age of 18 , when youngsters reach the age of legal majority. We obviously accept that new opportunities and responsibilities which become available might change individuals, but this

\footnotetext{
${ }^{21}$ These are seven indicators referring to Universidade de São Paulo, Escola E. Professor Ascendino Reis, Escola E. Rui Bloem, E. Professor Leopoldo Santana, Anglo Rua Sergipe, Anglo Rua Tamandaré, Anglo Av. João Dias.

${ }^{22}$ For the specification in Column 1, we find that females are under-represented on the right side of the threshold. In spite of that, we do not find evidence that gender explains voting behaviour in our sample or that voting has differential impacts among males and females.
} 
happens gradually and not abruptly at the 18th birthday. We tested whether students changed their behavior regarding their propensity to apply for college admission exams or to respond seriously to the survey at the threshold. In line with our expectations, none of these changed (Table 2).

Finally, there is the issue of self-reported data. This can result in non-random sorting across the threshold (i.e. the choice to participate in the survey correlates with participation in the election). In this case, a jump in the number of observations around the age of eighteen would be observed. Figure A1 in the Web Appendix shows a plot of the number of observations by age. The density of this variable at the threshold is smooth, and a formal test (based on McCrary, 2008) fails to reject the null hypothesis of no discontinuity at the cut-off point at the $86.17 \%$ level of significance. ${ }^{23}$

\section{$5 \quad$ Results}

In this section, we show IV estimates for the effect of voting on political knowledge and several measures of information acquisition. We find no statistically significant impact for any variable. Then we examine whether there are heterogeneous effects of voting on political knowledge across several subgroups and find no evidence of any statistically significant impact. Worth note is that, in using an instrumental variable approach, we estimate local average treatment effects. This method estimates the average treatment effect for compliers, or individuals who change their treatment status (i.e. become voters), because they react to the instrument (Imbens and Angrist, 1994). This is the population of forced voters. In interpreting a (non-) reaction, it is important to consider the fact that most of the adult Brazilian population votes. This probably elicits some peer pressure in inducing people to vote before turning eighteen (or vote voluntarily). Hence, in the context of a dual voting system, it is possible that these effects are estimated for a population less willing to be engaged in politics than an average non-voter in a single voting system, like in the U.S. ${ }^{24}$ Overall, our findings indicate that, when forced to vote, the population does not react by acquiring information and

\footnotetext{
${ }^{23}$ We also find no significant discontinuities in the distribution of observations in each of the subgroups considered in Section IV B.

${ }^{24}$ Although we can only identify effects among forced voters ("compliers"), and not for voluntary ones ("always takers"), our findings may be more general. As will be shown in Figure 1, there is a strong increase in the fraction of voters among the 17-year old population, possibly due to reasons related to the compulsory legislation like peer effects or anticipation to the obligation to vote, with no respective increase in political knowledge.
} 
becoming more knowledgeable about politics.

\subsection{Effects of Voting on Political Information}

Figure 1 illustrates the intuition for the result that people do not acquire costly information to vote. It plots the average outcome residual values in a 12-day interval. Residuals are obtained by regressing outcome on school-fixed effects, an indicator for whether the participant voted before and demographic characteristics (mother's education, gender and race indicators). Hollow circles indicate values for voter participation, and black circles represent the level of political knowledge (measured by the proportion of correct answers in the political quiz). For ease of visualization, we include predicted lines based on local linear regressions using a rectangular kernel and a bandwidth of nine months on each side of the cutoff.

While the exposure to compulsory voting has a clear and large impact in increasing voting turnout, a similar pattern is not visible for knowledge about politics; in fact, this variable's plot is close to a flat line throughout the age domain. The null voting effect is then straightforward, as the implied IV estimate of the causal effect is the ratio of the estimated discontinuity in knowledge at age eighteen to the estimated discontinuity in turnout.

\section{Figure1}

Next, we turn to our parametric estimates for the impact of voting participation. We use lower-order age polynomials based on Akaike Information Criterion (AIC) of model selection. ${ }^{25}$ They also present a better fit of the data, based on root-mean-square errors and R-square criterion. In spite of this, all findings hold when we use higher-order polynomials. In terms of the sample, we present results for individuals between 16.75 and 19.25 years old (within fifteen months of the cutoff age). We find the same results when further restricting the sample for individuals within six months of the age they are legally required to vote, or using all observations collected in the survey, including individuals between 16 and 60 years old (these results are available upon request).

Before turning to our main findings, we comment on our first-stage results. The estimated coefficients for the effect of the exposure to compulsory voting on voting participation are consistent with the impression from Figure 1. They indicate that, at

\footnotetext{
${ }^{25}$ We also run regressions for specifications including higher-order polynomials and a set of 30-day bin dummies, and these indicators are not jointly statistically significant, suggesting that these polynomials are an overfit of the data (Lee and Lemieux 2010).
} 
the age of eighteen, there is a significant increase in the probability of voting turnout, roughly between 30-60\% (or between 15 and 27 percentage-points), depending on the specification and sample. These results are reported in the Web Appendix in Table A3. In all regressions, the estimates for the eighteenth birthday coefficient are highly significant (related t- statistics are always greater than 2) and F-statistics are high. These findings support our identification strategy and demonstrate the strength of our instrument.

In Table 3, we describe results of the impact of voting on performance in the political quiz. We begin showing, in the first two columns, OLS estimates to examine the correlation between political knowledge and voting participation. In column 1, we control for a quadratic age polynomial flexible on each side of the threshold and demographic controls. The estimated voting coefficient implies that voters score 0.073 percentage points higher than non-voters in the political quiz. In the second column, we replicate controls in the first row, but use a linear polynomial in age flexible on each side of the threshold. We find practically the same point estimate for the voting coefficient. Taking into consideration the average performance of the population younger than 18 (described at the bottom of Table 3), these estimates indicate that voters perform roughly $15 \%$ better than non-voters in the political quiz. Column 3 presents the IV results for a specification controlling for demographics and using a quadratic age polynomial. The coefficient for the effect of voting is not statistically significant, and it is close to zero. The result does not change when we exclude demographic controls (column 4) or when we control for a polynomial linear in age (column 5). In columns 6 and 7, we show the results when narrowing the sample to individuals between 17.5 and 18.5 (within 6 months of the cutoff) or individuals between 17.75 and 18.25 (within three months of the cutoff) and replicating controls from column 5. For these regressions, the voting coefficients drop significantly, becoming negative, but they are, again, non-statistically significant. As noted, the voting coefficient in Table 3 is centered on zero for most specifications using the larger sample. However, standard errors are moderately large. Focusing on the specification in column 5, the estimates on the voting coefficient and respective standard error imply a ninety-five percent confidence level, roughly between -0.093 and 0.098 .

\section{Table 3}

In any case, we also test for other knowledge variables, isolating in the quiz individuals' knowledge about candidates' party affiliation, policies implemented by candidates, 
and comprehension of the ideological political spectrum. We do not find statistically significant effects of voting in determining these variables, as also shown in Table A4 in the Web Appendix. Overall, the estimates in Tables 3 and A4 largely corroborate null voting effects on political knowledge.

In Table 4, we present the IV results using several self-reported mechanisms of information acquisition as dependent variables, focusing on the main sample and on the specification controlling for full controls and a linear polynomial in age. The outcomes shown at the top of Table 4 include the following variables: whether participants always read the politics section in newspapers, the frequency with which they follow politics on newspapers and magazines, and the frequency with which they discuss politics with friends and parents. ${ }^{26}$ At the bottom of Table 4, we present estimates for the effects of voting participation on the frequency at which individuals consumed political information during the 2010 electoral season in TV news, on the Internet, and through presidential debates and TV campaign ads. ${ }^{27}$ We do not detect a statistically significant effect of voting for any outcomes. In IV regressions not presented in the paper, we find the same results restricting the sample to individuals within six or three months of the age cutoff.

\section{Table4}

Of note, some of the IV estimates are fairly noisy, and lack of precision might jeopardize our conclusions. To provide extra evidence of non-existent voting impacts, we turn to the effect of compulsory voting by showing the reduced form for the effect of whether the individual is 18 or older on Election Day. We conduct regressions considering different control specifications and samples. The results for all outcomes in this study are presented in Table A5, columns 1-4, in the Web Appendix. Overall, these coefficients are more precisely estimated than the voting impact in the IV regressions is. They largely indicate non-statistically significant effects of compulsory voting on information acquisition. In line with these RD regressions, non-parametric tests also detect no difference in behaviour by those that turn eighteen just before or just after

\footnotetext{
${ }^{26}$ These were multiple-choice questions in which students were presented with four alternatives about the frequency of discussion: (a) never, (b) rarely, (c) often, and (d) very often. We rank those in a 4-point scale, ranging from (a) to (d), and normalize these variables to have a mean of zero and a standard deviation of one.

${ }^{27}$ The frequency of following politics in newspapers, TV news or the internet refers to the number of days per week. Presidential debates and TV campaigns refers to the total number of times watched during the electoral season.
} 
Election Day. We follow Hanh, Todd, and Van der Klaauw (2001) and Porter (2003) and take the difference at the boundary points of two local linear regressions using a rectangular kernel and checking for several bandwidths (as recommended by Lee and Lemieux 2010). Following the literature, we estimate asymptotic standard errors using the formula from Porter (2003). ${ }^{28}$

Graphical evidence is presented in Figure 2, and the regression results are shown in Table A5, columns 5-7, in the online Appendix. The estimated discontinuity coefficients indicate the absence of a voting effect on all outcomes except for the number of TV political campaigns watched during the electoral season, significant at the $10 \%$ level for a bandwidth of six months. According to this specification, the exposure to compulsory voting leads to an increase between one and two watched programs in the electoral season. Worth note is that these political slots are broadcasted on prime-time of free TV channels, ${ }^{29}$ and hence are a source of political information for which citizens do not have to search actively. They also do not contribute to an increase in knowledge, as shown above.

Figures2

\subsection{Heterogeneity of Voting Effects on Political Knowledge}

Next, we check whether the results for the impact of voting on knowledge in the pooled sample are masking different impacts across subgroups in the population. In reasoning why heterogeneous effects can be relevant, we consider the political background at that time. By 2010, the incumbent president, Lula, had been in power for eight years, having implemented many social policies aimed at reducing inequality in the country. ${ }^{30}$ Poverty and unemployment rates decreased substantially (Musacchio 2008), and the media credited candidate Dilma Rousseff's popularity to Lula's legacy

${ }^{28}$ We thank Douglas Miller for providing the code from Ludwig and Miller (2007).

${ }^{29}$ In Brazil, the electoral law stipulates that, 45 days before the election, television networks must allocate two 50-minute slots of their grids per day to political campaign advertising (TSE). In total, nearly 180 political ads were broadcasted during the 2010 electoral season.

${ }^{30}$ These include the increase in the minimum wage to its highest level in real terms since 1979 and a significant expansion of the coverage of the Bolsa Familia Program. This program currently provides cash to approximately 12 million beneficiaries. The scheme is such that the government provides families earning less than $\$ 60$ per month a cash transfer that varies between U $\$ 7$ and US $\$ 40$, depending on income level. In exchange, the beneficiaries commit to keeping their children in school and receiving regular medical visits and vaccinations at home. 
(she was his chosen successor), especially among lower-income individuals. In addition, this group faces a higher cost in acquiring information. ${ }^{31}$ From this perspective, lower-income participants - in this paper's case, students with a mother with no college education - are expected to be less likely to acquire information to vote.

In Table 5, we present IV estimates for voting effects across several subgroups. We do not detect impacts by mother education, race or gender (columns 2-9). Coefficients are not statistically significant, and a formal chi-square test does not reject the hypothesis of equality of coefficients for any group (bottom row). We also separate groups by whether the individuals' mother has a party preference (as reported by the participant). This variable is used as a proxy for individuals' location in a political spectrum, since in our sample, a student whose mother prefers a particular party is less likely to be centeroriented (or middle of the road). ${ }^{32}$ Although this is a noisy and perhaps endogenous measure for ideology, this characteristic is key in explaining information acquisition in voting models (Degan 2006, Feddersen and Sandroni 2006a). Again, the related coefficients in columns 8 and 9 are not statistically significant. Overall, the consistency and robustness of estimates for the impact voting, considering distinct specifications, samples and variables, leads to the conclusion that voting participation does not have a contemporaneous effect on information acquisition.

Table 5

\section{Conclusion}

This paper presents evidence consistent with the rational ignorance hypotheses, tested in the context of compulsory voting. We do not find any effect of voting on information acquisition. Our results show that, at least for the forced voters - which in Brazil are more than a third of the number of voluntary voters ${ }^{33}$ - the consumption of political information comes from other reasons than getting ready to vote (e.g. interest in politics, having informal discussion with friends).

This finding is in line with the hypothesis presented by Downs (1957) and with

\footnotetext{
${ }^{31}$ For example, among lower-income classes (households whose monthly income is lower than 3 minimum salaries), $11 \%$ have a computer with access to Internet at home, and $76 \%$ have a radio. These rates are $51 \%$ and $86 \%$, respectively, for the remainder of the population (IBGE).

${ }^{32}$ This correlation is also observed the literature (Settle, Dawes and Fowler 2009).

${ }^{33}$ This number is based on our estimates, presented in Table A3, and the fact that close to $37 \%$ of those younger than 18 vote.
} 
predictions from economic models of strategic voting (Martinelli 2006, 2007). Downs's framework emphasizes the instrumental value of voting, which is often questioned as a suitable explanation for understanding participation in large elections (Feddersen 2004, Borgers 2004). On the other hand, it seems consistent with our perhaps surprising results of people's decision not to educate their votes.

Our findings contrast with the well-established result related to the reverse causality of information on voting (Lassen 2005, Gentzkow 2006, Banerjee et al. 2010). For example, in a field experiment in India, Banerjee, Kumar, Pande and Su (2010) found that, in receiving information about candidates' qualifications and legislators' performance, people became more likely to vote. Information can change people's preferences, trigger their interest in politics and affect their participation in elections. ${ }^{34}$

In this paper, we find that forcing people to vote is a much less powerful incentive to induce involvement in politics than providing information to citizens. Our results also refute an argument advocated by Lijphart (1997, p. 10) regarding the benefits of compulsory voting, namely its potential "to serve as an equivalent form of civic education and political stimulation." In our data, we do not detect changes in political knowledge amongst the population when moving from a voluntary to a compulsory voting system. A general observation, also in our sample, is that (voluntary) voters are more informed than non-voters (Palfrey and Poole, 1987). The direct implication of our results is that the electorate under full and forced democracy is likely to be less informed than a self-selected electorate, possibly having direct effects on election outcomes (Leon 2013, Bartels 1996.)

\section{References}

[1] Anderson, Barbara and Brian Silver. 1986. "Measurement and Mismeasurement of the Validity of the Self-Reported Vote." American Journal of Political Science 30 (4): 771-785.

[2] Banerjee, Abhijit, Selvan Kumar, Rohini Pande and Felix Su. 2010. "Do Informed Voters Make Better Choices? Experimental Evidence from Urban India." Working Paper, MIT.

[3] Bartels, Larry. 1996. "Uninformed Votes: Information Effects in Presidential Elec-

\footnotetext{
${ }^{34}$ Alternatively, as proposed by Feddersen and Pesendorfer (1996) and empirically verified in the laboratory by Battaglini, Morton and Palfrey (2008), non-informed citizens might delegate the task of deciding the election to their informed counterparts, partially by abstaining from voting.
} 
tions." American Journal of Political Science 40 (1): 194-230.

[4] Battaglini Marco, Rebecca Morton and Thomas Palfrey. 2010. "The Swing Voter's Curse in the Laboratory." Review of Economic Studies 77(1): 61-89.

[5] Berggren, Heidi. 2001. "Institutional Context and Reduction of the Resource Bias in Political Sophistication." Political Research Quarterly 54(3): 531-552.

[6] Borgers, Tilman. 2004. "Costly voting." American Economic Review 94 (1): 57-66.

[7] Coate, Stephen and Michael Conlin. 2004. "A Group Rule-Utilitarian Approach to Voter Turnout: Theory and Evidence." American Economic Review 94(5): 1476-504.

[8] Degan, Arianna. 2007. "Candidate Valence: Evidence from Consecutive Presidential Elections." International Economic Review 48(2): 457-482.

[9] Degan, Arianna. 2006. "Policy Positions, Information Acquisition and Turnout." The Scandinavian Journal of Economics 108(4): 669-682.

[10] Degan, Arianna and Antonio Merlo. 2011. "A Structural Model of Turnout and Voting in Multiple Elections," Journal of the European Economic Association 9(2): 209-245.

[11] Delli Carpini, Michael and Scott Keeter. What Americans Know about Politics and Why It Matters. 1996. Yale University Press.

[12] Downs, Anthony. 1957. An economic theory of democracy. New York: Harper and Row.

[13] Elinder, Mikael. 2012. "Correcting mistakes: cognitive dissonance and political attitudes in Sweden and the United States." Public Choice 153 (1-2):235-249.

[14] Feddersen, Timothy and Wolfgang Pesendorfer. 1996. "The Swing Voter's Curse." American Economic Review 86(3): 408-424.

[15] Feddersen, Timothy. 2004. "Rational Choice Theory and the Paradox of Not Voting." The Journal of Economic Perspectives 18(1): 99-112.

[16] Feddersen, Timothy and Alvaro Sandroni. 2006a. "Ethical Voters and Costly Information Acquisition", Quarterly Journal of Political Science 1(3): 287-311.

[17] Feddersen, Timothy and Alvaro Sandroni. 2006b. "A theory of participation in elections." American Economic Review 96(4): 1271-1282.

[18] Gentzkow, Matthew. 2006. "Television and Voter Turnout." Quarterly Journal of Economics 121(3): 931-72. 
[19] Gerber, Alan, Gregory Huber, Ebonya Washington. 2010. "Party Affiliation, Partisanship, and Political Beliefs: A Field Experiment." American Political Science Review 104(4): 720-744.

[20] Gerber Alan, Donald Green and Ron Shachar. 2003. "Voting May Be HabitForming: Evidence from a Randomized Field Experiment." American Journal of Political Science 47(3): 540-550.

[21] Gordon, Stacy and Gary M. Segura. 1997. "Cross-National Variation in the Political Sophistication of Individuals: Capability or Choice?" The Journal of Politics 59(1): 126-147.

[22] Hahn, Jinyong, Petra Todd and Wilbert Van der Klaauw. 2001. "Identification and Estimation of Treatment Effects with a Regression-Discontinuity Design." Econometrica 69(1): 201-209.

[23] Imbens, Guido and Joshua D. Angrist. 1994. "Identification and Estimation of Local Average Treatment Effects." Econometrica 62 (2): 467-475.

[24] Krasa, Stefan and Mattias Polborn. 2005. "Is Mandatory Voting Better Than Voluntary Voting?" Games and Economic Behavior 66 (1): 275-291.

[25] Krishna, Vijay and John Morgan. 2011. "Overcoming Ideological Bias in Elections." Journal of Political Economy 119 (2): 183-211.

[26] Lassen, David. 2005. "The Effect of Information on Voter Turnout: Evidence from a Natural Experiment" American Journal of Political Science 49(1): 103-18.

[27] Lee, David and Thomas Lemieux. 2010. "Regression Discontinuity Designs in Economics." Journal of Economic Literature 48(2): 281-355.

[28] Leon, Fernanda L. L. de. 2013. "Adding Ideology to the Equation: New Predictions for Effects of Compulsory Voting. "Working Paper. University of East Anglia.

[29] Lijphart, Arend. 1997. "Unequal Participation: Democracy's Unresolved Dilemma." American Political Science Review 91(1):1-14.

[30] Ludwig, Jens and Douglas L. Miller. 2007. "Does Head Start Improve Children's Life Chances? Evidence from a Regression Discontinuity Approach." Quarterly Journal of Economics 122(1): 159-208.

[31] Loewen, Peter, Henry Milner and Bruce Hicks. 2008. "Does Compulsory Voting Lead to More Informed and Engaged individuals? An Experimental Test." Canadian Journal of Political Science 41:655-672. 
[32] Martinelli, Cesar. 2007. "Rational Ignorance and Voting Behavior." International Journal of Game Theory 35: 315-335.

[33] Martinelli, Cesar. 2006. "Would Rational Voters Acquire Costly Information?" Journal of Economic Theory 129 (1): 225-251.

[34] Matsusaka, John. 1995. "Explaining Voter Turnout Patterns: An Information Theory." Public Choice 84(1-2): 91-117.

[35] McCrary, Justin. 2008. "Manipulation of the Running Variable in the Regression Discontinuity Design: A Density Test." Journal of Econometrics 142(2): 698714.

[36] Meredith Marc. 2009. "Persistence in Political Participation," Quarterly Journal of Political Science, 4(3): 186-208.

[37] Merlo, Antonio. 2006. "Whither Political Economy." in Advances in Economics and Econometrics: Theory and Applications Ninth World Congress of the Econometric Society, Vol I, eds. Richard Blundell, Whitney Newey and Torsten Persson. New York: Cambridge University Press.

[38] Michelson, Melissa R and David W. Nickerson. 2011. "Voter Mobilization", in Cambridge Handbook of Experimental Political Science, eds. James N. Druckman, Donald P. Green, James H. Kuklinski, Arthur Lupia. New York: Cambridge University Press.

[39] Mullainathan, Sendhil and Ebonya Washington. 2009. "Sticking With Your Vote: Cognitive Dissonance and Political Attitudes." American Economic Journal: Applied Economics 1(1): 86-111.

[40] Musacchio, Aldo. 2008. "Brazil under Lula: Off the Yellow BRIC Road." Working Paper. Harvard Business School.

[41] Nickerson, David. 2008. "Is Voting Contagious? Evidence from Two Field Experiments." American Political Science Review 102(1): 49-57.

[42] Palfrey, Thomas and Keith Poole. 1987. "The Relationship Between Information, Ideology and Voting Behavior." American Journal of Political Science 31(3): 511-530.

[43] Pew Research Center. 2010. "Public Knows Basic Facts about Politics, Economics, But Struggles with Specifics." (http://www.pewresearch.org/2010/11/18/public-knows-basic-facts-aboutpolitics-economics-but-struggles-with-specifics/). 
[44] Porter, Jack. 2003. "Estimation in the Regression Discontinuity Model." Working Paper. Department of Economics. University of Wisconsin at Madison.

[45] Seebauer, Michael and Jens Grober. 2013. "The curse of uninformed voting: An experimental study." Working paper, University of Cologne.

[46] Settle, Jaime, Christopher Dawes and James Fowler. 2009. "The Heritability of Partisan Attachment." Political Research Quarterly, 62 (3): 601-613.

[47] Shachar, Ron and Barry Nalebuff. 1999. "Follow the Leader: Theory and Evidence on Political Participation." American Economic Review, 89(3): 525-47.

[48] Swaddle, Kevin and Anthony Heath. 1989. "Official and Reported Turnout in the British General Election of 1987". British Journal of Political Science 19(4): $537-551$. 


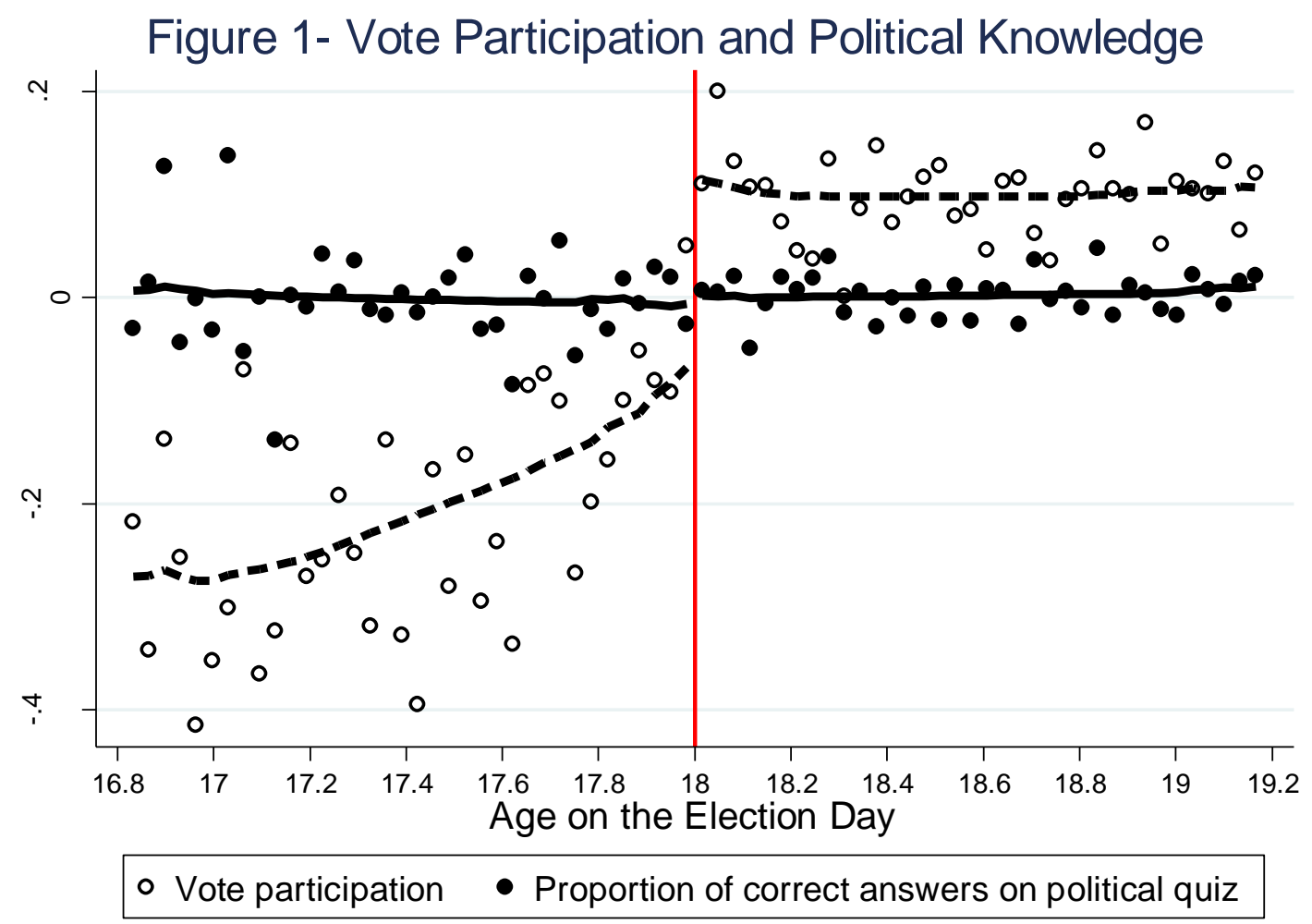

Circles indicate average residual values in a 12-day interval. Lines are predicted from local linear regressions using a rectangular kernel and a bandwidth of nine months. 


\section{Figures 2}
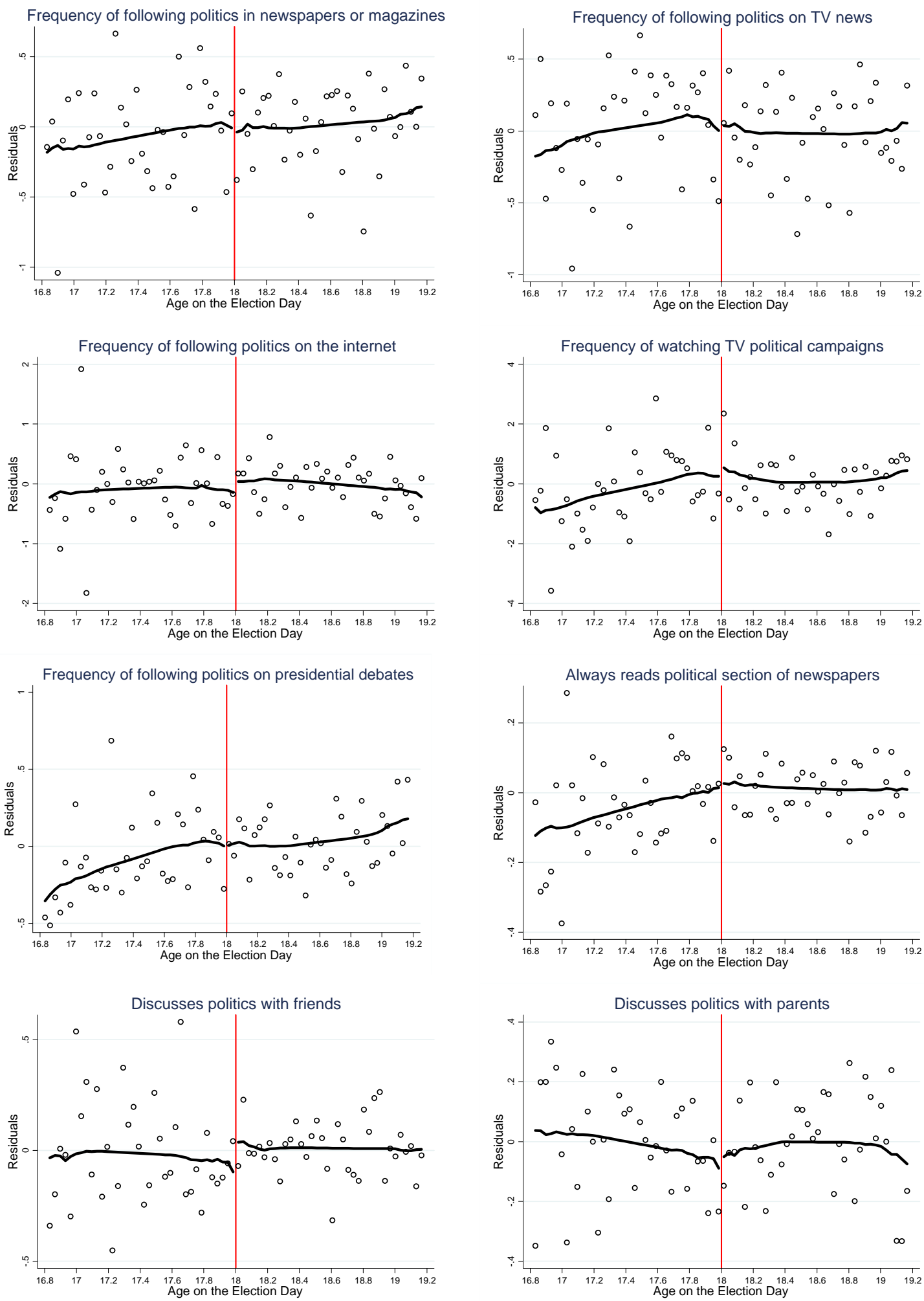

Note: Circles indicate average residual outcome values in a 12-day interval. Lines are predicted from local linear regressions using a rectangular kernel and a bandwidth of nine months. 


\begin{tabular}{lcccc}
\hline \hline & {$[1]$} & {$[2]$} & $\mathrm{N}$ \\
\cline { 2 - 4 } Dependent variable: & & & \\
White & 0.0111 & 0.0052 & 3,046 \\
Female & {$[0.0303]$} & {$[0.0432]$} & \\
& -0.0763 & -0.0649 & 3,069 \\
Mother has college education & {$[0.0359]^{* *}$} & {$[0.0498]$} & \\
& 0.0399 & 0.0501 & 3,058 \\
Lives with parent(s) & {$[0.0297]$} & {$[0.0414]$} & \\
& -0.0178 & 0.0251 & 3,072 \\
Works & {$[0.0227]$} & {$[0.0321]$} & \\
& -0.0261 & -0.0383 & 2,806 \\
Voted before & {$[0.0216]$} & {$[0.0308]$} & \\
& 0.0555 & 0.0361 & 3,205 \\
Responded seriously to the survey & {$[0.0137]^{* *}$} & {$[0.0191]^{*}$} & \\
& 0.0227 & 0.0048 & 3,167 \\
Plans to apply to College & {$[0.0186]$} & {$[0.0247]$} & \\
& -0.0034 & 0.0104 & 2,654 \\
Frequency of church attendance (times per month) & {$[0.0229]$} & {$[0.0330]$} & \\
& -0.3024 & -0.2019 & 2,759 \\
Mother has a party preference & {$[0.2367]$} & {$[0.3522]$} & \multirow{2}{*}{2,646} \\
& -0.0264 & 0.0421 & \\
\hline Age polynomial controls & {$[0.0404]$} & {$[0.0564]$} & \\
\hline Notes: The sample includes individuals between 16.75 and 19.25 years old.Entries represent OLS regression results \\
including age polynomial controls fully interacted with a dummy for age 18 or older, and school fixed effects. \\
Huber White standard errors are in brackets. **Significant at the 5 percent level. *Significant at the 10 percent level.
\end{tabular}


TABLE 3 - EFFECTS OF VOTER TURNOUT ON POLITICAL KNOWLEDGE

\begin{tabular}{|c|c|c|c|c|c|c|c|}
\hline \multirow{3}{*}{ Independent Variable } & \multicolumn{7}{|c|}{ "Dependent Variable: Proportion of Correct Answers in the Political Quiz } \\
\hline & [1] & [2] & [3] & [4] & [5] & [6] & [7] \\
\hline & & & & & & & \\
\hline \multirow[t]{2}{*}{ Vote Paticipation } & 0.0734 & 0.0720 & -0.0047 & 0.0027 & 0.0023 & -0.0067 & -0.1154 \\
\hline & {$[0.0091]^{* * *}$} & {$[0.0090]^{* * *}$} & {$[0.0991]$} & {$[0.0946]$} & [0.0487] & [0.1017] & [0.1999] \\
\hline Method & OLS & OLS & IV & IV & IV & IV & IV \\
\hline Age polynomial controls & Quadratic & Linear & Quadratic & Quadratic & Linear & Linear & Linear \\
\hline Other controls & Yes & Yes & Yes & No & Yes & Yes & Yes \\
\hline Sample (in age) & {$[16.75,19.25]$} & {$[16.75,19.25]$} & {$[16.75,19.25]$} & {$[16.75,19.25]$} & {$[16.75,19.25]$} & {$[17.5,18.5]$} & {$[17.75,18.25]$} \\
\hline $\mathrm{N}$ & 3,013 & 3,013 & 3,013 & 3,196 & 3,013 & 1,397 & 747 \\
\hline Mean younger than 18 & 0.497 & 0.497 & 0.497 & 0.497 & 0.497 & 0.508 & 0.520 \\
\hline
\end{tabular}

Notes: All regressions including controls for an age polynomial fully interacted with a dummy for age 18 or older, school fixed effects and an indicator for

whether the respondent voted before. Other controls are indicators for mother education, race and gender. Huber White standard errors are in brackets.

$* * *$ Significant at the 1 percent level. 
TABLE 4 - IV EFFECTS OF VOTER TURNOUT ON MECHANISMS OF INFORMATION ACQUISITION

Dependent Variables

\begin{tabular}{|c|c|c|c|c|}
\hline & \multicolumn{4}{|c|}{ Dependent Variables } \\
\hline & \multirow{2}{*}{$\begin{array}{l}\text { Always reads political } \\
\text { section of newspapers }\end{array}$} & \multirow{2}{*}{$\begin{array}{c}\text { Frequency of following } \\
\text { politics in newspapers }\end{array}$} & \multicolumn{2}{|c|}{ Discusses politics with: } \\
\hline & & & Friends & Parents \\
\hline \multirow[t]{2}{*}{ Vote Paticipation } & 0.0849 & -0.3077 & 0.2862 & 0.1837 \\
\hline & {$[0.1742]$} & [0.5443] & {$[0.2711]$} & {$[0.2778]$} \\
\hline $\mathrm{N}$ & 2,080 & 2,955 & 3,012 & 3,000 \\
\hline \multirow[t]{3}{*}{$\begin{array}{c}\text { Mean dependent variable } \\
\text { for younger than } 18\end{array}$} & 0.499 & 2.087 & -0.014 & 0.088 \\
\hline & \multicolumn{4}{|c|}{ Frequency of following politics in: } \\
\hline & TV news & Internet & Presidential debates & TV campaign \\
\hline \multirow[t]{2}{*}{ Vote Paticipation } & -0.6038 & 0.7541 & -0.1757 & -1.1755 \\
\hline & [0.5813] & {$[0.6271]$} & {$[0.3530]$} & [1.6929] \\
\hline $\mathrm{N}$ & 2,984 & 2,961 & 2,973 & 2,913 \\
\hline $\begin{array}{c}\text { Mean dependent variable } \\
\text { for younger than } 18\end{array}$ & 3.778 & 3.037 & 1.621 & 7.054 \\
\hline
\end{tabular}

Notes: The sample consists individuals between 16.75 and 19.25 years old. The frequency of following politics in newspapers, TV news or the internet refers to the number of days per week. Presidential debates and TV campaigns refers to the total number of times watched during the electoral season.

Entries are IV regressions results from a linear age polynomial fully interacted with a dummy for age 18 or older, school fixed effects and indicators for whether the respondent voted before, mother education, race and gender. Huber White standard errors are in brackets. 


\section{TABLE 5 - IV EFFECTS OF VOTER TURNOUT ON POLITICAL KNOWLEDGE - HETEROGENEOUS IMPACTS}

\begin{tabular}{|c|c|c|c|c|c|c|c|c|c|}
\hline & \multirow[b]{3}{*}{$\begin{array}{l}\text { All } \\
{[1]}\end{array}$} & \multicolumn{8}{|c|}{ Dependent Variable: Proportion of Correct Answers in the Political Quiz } \\
\hline & & \multicolumn{2}{|c|}{$\begin{array}{c}\text { Mother has college } \\
\text { education }\end{array}$} & \multicolumn{2}{|c|}{ Gender } & \multicolumn{2}{|c|}{ Race } & \multicolumn{2}{|c|}{$\begin{array}{c}\text { Mother has a } \\
\text { party preference }\end{array}$} \\
\hline & & $\begin{array}{l}\text { Yes } \\
{[2]}\end{array}$ & $\begin{array}{l}\text { No } \\
{[3]}\end{array}$ & $\begin{array}{c}\text { Female } \\
{[4]}\end{array}$ & $\begin{array}{c}\text { Male } \\
{[5]}\end{array}$ & $\begin{array}{c}\text { White } \\
{[6]}\end{array}$ & $\begin{array}{c}\text { Non-white } \\
\text { [7] }\end{array}$ & $\begin{array}{l}\text { Yes } \\
{[8]}\end{array}$ & $\begin{array}{l}\text { No } \\
{[9]}\end{array}$ \\
\hline Vote Paticipation & $\begin{array}{c}0.0280 \\
{[0.0472]}\end{array}$ & $\begin{array}{c}0.0275 \\
{[0.0643]}\end{array}$ & $\begin{array}{c}0.0326 \\
{[0.0720]}\end{array}$ & $\begin{array}{c}0.0122 \\
{[0.0537]}\end{array}$ & $\begin{array}{c}0.0016 \\
{[0.1056]}\end{array}$ & $\begin{array}{c}0.0088 \\
{[0.0656]}\end{array}$ & $\begin{array}{c}0.0268 \\
{[0.0721]}\end{array}$ & $\begin{array}{c}-0.0052 \\
{[0.0873]}\end{array}$ & $\begin{array}{c}-0.0417 \\
{[0.0820]}\end{array}$ \\
\hline $\begin{array}{l}\text { Mean dependent variable } \\
\text { for younger than } 18\end{array}$ & 0.497 & 0.543 & 0.456 & 0.489 & 0.515 & 0.520 & 0.454 & 0.544 & 0.525 \\
\hline $\mathrm{N}$ & 3,196 & 2,032 & 1,013 & 1,791 & 1,264 & 2,325 & 707 & 1,173 & 1,463 \\
\hline$\chi^{2}$ test of equal coefficients & & \multicolumn{2}{|c|}{0.0028} & \multicolumn{2}{|c|}{0.0081} & \multicolumn{2}{|c|}{0.0339} & \multicolumn{2}{|c|}{0.0929} \\
\hline p-value & & \multicolumn{2}{|c|}{0.9574} & \multicolumn{2}{|c|}{0.9283} & \multicolumn{2}{|c|}{0.8539} & \multicolumn{2}{|c|}{0.7605} \\
\hline
\end{tabular}

Notes: The sample consists individuals between 16.75 and 19.25 years old. Entries are IV regressions results from a linear age polynomial fully interacted with a dummy for age 18 or older, school fixed effects and an indicator for whether the respondent voted before. Huber White standard errors are in brackets. 
“A Test for the Rational Ignorance Hypothesis: Evidence from a Natural Experiment in Brazil”

Appendix 
TABLE A1 - SUMMARY STATISTICS BY AGE SAMPLE

\begin{tabular}{|c|c|c|c|c|c|c|c|c|c|}
\hline \multirow[t]{3}{*}{ Sample (in age): } & \multicolumn{3}{|c|}{16.75 to 19.25} & \multicolumn{3}{|c|}{17.5 to 18.5} & \multicolumn{3}{|c|}{17.75 to 18.25} \\
\hline & \multicolumn{3}{|c|}{ Standard } & \multicolumn{3}{|c|}{ Standard } & \multicolumn{3}{|c|}{ Standard } \\
\hline & Mean & Deviation & $\mathrm{N}$ & Mean & Deviation & $\mathrm{N}$ & Mean & Deviation & $\mathrm{N}$ \\
\hline \multicolumn{10}{|l|}{ Characteristics (in \%) } \\
\hline White & 0.767 & 0.423 & 3,046 & 0.763 & 0.425 & 1,415 & 0.751 & 0.433 & 756 \\
\hline Female & 0.585 & 0.493 & 3,069 & 0.597 & 0.491 & 1,427 & 0.586 & 0.493 & 761 \\
\hline Mother has college education & 0.666 & 0.472 & 3,058 & 0.655 & 0.475 & 1,418 & 0.664 & 0.472 & 757 \\
\hline Live with parent(s) & 0.857 & 0.350 & 3,072 & 0.873 & 0.333 & 1,428 & 0.869 & 0.338 & 762 \\
\hline Works & 0.072 & 0.259 & 2,806 & 0.081 & 0.272 & 1,302 & 0.086 & 0.280 & 690 \\
\hline Voted before & 0.111 & 0.314 & 3,205 & 0.061 & 0.239 & 1,481 & 0.048 & 0.214 & 789 \\
\hline Responded seriously to the survey & 0.931 & 0.253 & 3,167 & 0.934 & 0.249 & 1,463 & 0.937 & 0.243 & 777 \\
\hline Plan to apply to College & 0.923 & 0.266 & 2,654 & 0.914 & 0.281 & 1,229 & 0.903 & 0.296 & 652 \\
\hline Frequency of church attendance (number per month) & 1.211 & 2.950 & 2,759 & 1.299 & 3.182 & 1,287 & 1.320 & 3.184 & 678 \\
\hline Mother has a party preference & 0.444 & 0.497 & 2,646 & 0.458 & 0.498 & 1,214 & 0.461 & 0.499 & 644 \\
\hline Universidade de Sao Paulo & 0.116 & & 3,236 & 0.110 & & 1,494 & 0.113 & & 794 \\
\hline Anglo Vestibulares & 0.667 & & 3,236 & 0.649 & & 1,494 & 0.635 & & 794 \\
\hline Public High School & 0.217 & & 3,236 & 0.242 & & 1,494 & 0.252 & & 794 \\
\hline \multicolumn{10}{|l|}{ Outcomes } \\
\hline Voted in the 2010 Election & 0.719 & 0.450 & 3,224 & 0.711 & 0.453 & 1,488 & 0.716 & 0.451 & 790 \\
\hline$\%$ Correct answers in the political quiz & 0.555 & 0.200 & 3,236 & 0.551 & 0.199 & 1,494 & 0.549 & 0.196 & 794 \\
\hline$\%$ Correct answers in questions concerning parties & 0.550 & 0.197 & 3,236 & 0.547 & 0.195 & 1,494 & 0.547 & 0.191 & 794 \\
\hline$\%$ Correct answers in questions concerning policies & 0.538 & 0.255 & 3,236 & 0.538 & 0.252 & 1,494 & 0.544 & 0.252 & 794 \\
\hline Identified the most right-wing party & 0.707 & 0.455 & 3,236 & 0.686 & 0.464 & 1,494 & 0.679 & 0.467 & 794 \\
\hline Always reads political section of newspapers & 0.603 & 0.489 & 2,211 & 0.609 & 0.488 & 1,016 & 0.612 & 0.488 & 536 \\
\hline \multicolumn{10}{|l|}{ Frequency of following politics in: } \\
\hline Newspapers or magazines & 2.280 & 2.018 & 3,176 & 2.226 & 1.971 & 1,460 & 2.253 & 1.962 & 778 \\
\hline TV news & 3.521 & 2.057 & 3,206 & 3.549 & 2.062 & 1,480 & 3.513 & 2.065 & 785 \\
\hline Internet & 3.267 & 2.364 & 3,183 & 3.242 & 2.351 & 1,469 & 3.232 & 2.353 & 780 \\
\hline TV political campaigns & 6.419 & 6.073 & 3,125 & 6.587 & 6.252 & 1,441 & 6.547 & 6.120 & 762 \\
\hline Presidential debates & 1.748 & 1.392 & 3,189 & 1.763 & 1.359 & 1,471 & 1.754 & 1.333 & 781 \\
\hline \multicolumn{10}{|l|}{ Discusses politics with: } \\
\hline Parents & 0.000 & 1.000 & 3,219 & -0.026 & 0.991 & 1,486 & -0.021 & 0.993 & 791 \\
\hline Friends & 0.001 & 0.999 & 3,230 & -0.008 & 0.985 & 1,492 & -0.011 & 0.970 & 793 \\
\hline Correct assessment about his/her requirement to vote' status & 0.954 & 0.210 & 2,851 & 0.924 & 0.264 & 1,323 & 0.894 & 0.308 & 700 \\
\hline
\end{tabular}


TABLE A2 - SELF-REPORTED TURNOUT BY AGE

\begin{tabular}{|c|c|c|c|}
\hline & Current Vote & trospective $\mathrm{V}$ & \\
\hline & Year of Birth (1 & ed Vote) & \\
\hline Age on Election Day & 1992 (2010) & 1988 (2006) & p-value (I=II) \\
\hline of Reported Vote & (I) & (II) & \\
\hline 17.47 & 23.81 & 42.11 & 10.76 \\
\hline & 84 & 19 & \\
\hline 17.55 & 35.37 & 34.62 & 94.50 \\
\hline & 82 & 26 & \\
\hline 17.63 & 37.18 & 50.00 & 28.30 \\
\hline & 78 & 22 & \\
\hline 17.71 & 42.86 & 35.29 & 56.85 \\
\hline & 84 & 17 & \\
\hline 17.79 & 39.60 & 53.33 & 31.79 \\
\hline & 101 & 15 & \\
\hline 17.88 & 57.01 & 52.94 & 75.57 \\
\hline & 107 & 17 & \\
\hline 17.96 & 61.34 & 62.50 & 92.96 \\
\hline & 119 & 16 & \\
\hline 18.04 & 85.00 & 83.33 & 85.40 \\
\hline & 140 & 18 & \\
\hline 18.12 & 86.34 & 100.00 & 19.14 \\
\hline & 161 & 11 & \\
\hline 18.21 & 81.94 & 87.50 & 69.04 \\
\hline & 155 & 8 & \\
\hline 18.29 & 85.71 & 90.00 & 70.70 \\
\hline & 161 & 10 & \\
\hline 18.37 & 90.44 & 62.50 & $1.44^{* *}$ \\
\hline & 136 & 8 & \\
\hline 18.45 & 87.58 & 75.00 & 30.50 \\
\hline & 161 & 8 & \\
\hline 18.53 & 89.74 & 80.00 & 25.40 \\
\hline & 156 & 15 & \\
\hline Aggregated Sample by [aq & & & \\
\hline Voluntary Voting: [17.5, 18] & 43.97 & 46.21 & 63.66 \\
\hline & 655 & 132 & \\
\hline Compulsory Voting: $[18,18.5]$ & 86.64 & 83.33 & 41.17 \\
\hline & 1,070 & 78 & \\
\hline
\end{tabular}

Notes: Numbers of observations are in italics. Current vote rates (in Column I) are based on self-reported vote participation in the 2010 Election. Retrospective vote rates (in Column II) are based on responses recovered from a multiple choice question about the first election they voted. 
Table A3- First Stage Results

Older than 18

$$
0.1859
$$

0.2694

0.1855

0.1414

on Election Day

$[0.0441]^{* * *}$

$[0.0320]^{* * *}$

$[0.0460]^{* * *}$

[0.0637]**

Mean dependent variable

0.3739

0.3739

0.4693

0.5321

for younger than 18

F-statistics

91.14

103.53

26.57

9.96

age polynomial

Quadratic

Linear

Linear

Linear

Sample in age

[16.75, 19.25]

[16.75, 19.25]

$[17.5,18.5]$

[17.75, 18.25]

$\mathrm{N}$

3,013

3,013

1,397

747

Notes: The dependent variable is an indicator for whether the participant voted in the 2010 Election.

Entries represent OLS regression results including age polynomial controls fully interacted with a

dummy for age 18 or older, school fixed effects and indicators for whether the respondent voted before,

mother education, race and gender. Huber White standard errors are in brackets.

*** significant at the 1 percent level, ** significant at the 5 percent levı 
TABLE A4 - IV EFFECTS OF VOTER TURNOUT ON EXTRA POLITICAL KNOWLEDGE VARIABLES

\begin{tabular}{|c|c|c|c|c|c|c|}
\hline \multirow[b]{2}{*}{ Method } & \multirow[b]{2}{*}{$\begin{array}{l}\text { Sample } \\
\text { (in age) }\end{array}$} & \multirow[b]{2}{*}{ Specification } & \multicolumn{3}{|c|}{ Dependent Variable: } & \multirow[b]{2}{*}{$\mathrm{N}$} \\
\hline & & & $\begin{array}{c}\text { \% Correct answ } \\
\text { Parties }\end{array}$ & $\begin{array}{l}\text { stions concerning: } \\
\text { Policies }\end{array}$ & $\begin{array}{l}\text { Identified the most } \\
\text { right-wing party } \\
\text { (among two alternatives) }\end{array}$ & \\
\hline OLS & {$[16.75,19.25]$} & $\begin{array}{l}\text { Second order polynomial in age } \\
\text { and demographics }\end{array}$ & $\begin{array}{c}0.0699 \\
{[0.0094]^{* * *}} \\
0.5055\end{array}$ & $\begin{array}{c}0.0636 \\
{[0.0123]^{* * *}} \\
0.4964\end{array}$ & $\begin{array}{c}0.0763 \\
{[0.0225]^{* * *}} \\
0.5546\end{array}$ & 3,013 \\
\hline OLS & {$[16.75,19.25]$} & $\begin{array}{l}\text { Linear polynomial in age } \\
\text { and demographics }\end{array}$ & $\begin{array}{c}0.0672 \\
{[0.0093]^{* *}} \\
0.5055\end{array}$ & $\begin{array}{c}0.0631 \\
{[0.0121]^{* * *}} \\
0.4964\end{array}$ & $\begin{array}{c}0.0802 \\
{[0.0221]^{* * *}} \\
0.5546\end{array}$ & 3,013 \\
\hline IV & {$[16.75,19.25]$} & $\begin{array}{l}\text { Second order polynomial in age } \\
\text { and demographics }\end{array}$ & $\begin{array}{c}0.0752 \\
{[0.0999]} \\
0.5055\end{array}$ & $\begin{array}{c}-0.1195 \\
{[0.1352]} \\
0.4964\end{array}$ & $\begin{array}{c}0.1199 \\
{[0.2503]} \\
0.5546\end{array}$ & 3,013 \\
\hline IV & {$[16.75,19.25]$} & $\begin{array}{l}\text { Second order polynomial in age } \\
\text { and no demographics }\end{array}$ & $\begin{array}{c}0.0768 \\
{[0.0949]} \\
0.5055\end{array}$ & $\begin{array}{c}-0.1239 \\
{[0.1289]} \\
0.4964\end{array}$ & $\begin{array}{c}0.1522 \\
{[0.2358]} \\
0.5546\end{array}$ & 3,196 \\
\hline IV & {$[16.75,19.25]$} & $\begin{array}{l}\text { Linear polynomial in age } \\
\text { and demographics }\end{array}$ & $\begin{array}{c}0.0005 \\
{[0.0501]} \\
0.5055\end{array}$ & $\begin{array}{c}-0.0367 \\
{[0.0655]} \\
0.4964\end{array}$ & $\begin{array}{c}0.2051 \\
{[0.1238]^{*}} \\
0.5546\end{array}$ & 3,013 \\
\hline IV & {$[17.5,18.5]$} & $\begin{array}{l}\text { Linear polynomial in age } \\
\text { and demographics }\end{array}$ & $\begin{array}{c}0.0259 \\
{[0.1027]} \\
0.5137\end{array}$ & $\begin{array}{c}-0.0834 \\
{[0.1369]} \\
0.5113\end{array}$ & $\begin{array}{c}0.1224 \\
{[0.2589]} \\
0.5672\end{array}$ & 1,397 \\
\hline IV & {$[17.75,18.25]$} & $\begin{array}{l}\text { Linear polynomial in age } \\
\text { and demographics }\end{array}$ & $\begin{array}{c}0.0757 \\
{[0.1905]} \\
0.5208\end{array}$ & $\begin{array}{c}-0.3797 \\
{[0.3064]} \\
0.5319\end{array}$ & $\begin{array}{c}-0.3157 \\
{[0.4939]} \\
0.5957\end{array}$ & 747 \\
\hline
\end{tabular}

Notes: Entries are IV regressions results from a age polynomial fully interacted with a dummy for age 18 or older, school fixed effects and an indicator for whether the respondent voted before. Demographics include mother education, race and gender. Huber White standard errors are in brackets. In italic is the mean dependent variable for younger than 18.

***Significant at the 1 percent level, **Significant at the 5 percent level, *Significant at the 10 percent level. 
TABLE A5 - RD ESTIMATES FOR DISCONTINUITIES AT AGE 18

\begin{tabular}{|c|c|c|c|c|c|c|c|c|c|c|c|}
\hline \multirow[b]{3}{*}{ Denendent Variable• } & \multicolumn{7}{|c|}{ Parametric estimates by Age Functional Form and Sample } & \multicolumn{3}{|c|}{ Non-parametric estimates by bandwidth (in months) } & \\
\hline & \multirow{2}{*}{$\begin{array}{c}\text { [1] } \\
\text { Quadratic }\end{array}$} & \multicolumn{2}{|l|}{ [2] } & \multicolumn{2}{|l|}{ [3] } & \multicolumn{2}{|l|}{ [4] } & \multirow{2}{*}{$\begin{array}{c}5] \\
12\end{array}$} & \multirow{2}{*}{$\begin{array}{c}6] \\
9 \\
\end{array}$} & \multicolumn{2}{|l|}{ [7] } \\
\hline & & Linear & $\mathrm{N}$ & Linear & $\mathrm{N}$ & Linear & $\mathrm{N}$ & & & 6 & $\mathrm{~N}$ \\
\hline \% Correct answers in the political quiz & $\begin{array}{c}-0.0009 \\
{[0.0184]}\end{array}$ & $\begin{array}{c}0.0012 \\
{[0.0132]}\end{array}$ & 3,019 & $\begin{array}{c}-0.0009 \\
{[0.0188]}\end{array}$ & 1,399 & $\begin{array}{c}-0.0179 \\
{[0.0262]}\end{array}$ & 749 & $\begin{array}{c}0.0035 \\
{[0.0136]}\end{array}$ & $\begin{array}{c}0.0035 \\
{[0.0155]}\end{array}$ & $\begin{array}{c}-0.0012 \\
{[0.0187]}\end{array}$ & 2,816 \\
\hline Consumption of Information & & & & & & & & & & & \\
\hline Always reads political section of newspapers & $\begin{array}{c}0.0441 \\
{[0.0598]}\end{array}$ & $\begin{array}{c}0.0207 \\
{[0.0433]}\end{array}$ & 2,082 & $\begin{array}{c}0.0466 \\
{[0.0615]}\end{array}$ & 951 & $\begin{array}{c}0.1337 \\
{[0.0855]}\end{array}$ & 507 & $\begin{array}{c}0.0223 \\
{[0.0429]}\end{array}$ & $\begin{array}{c}0.0256 \\
{[0.0492]}\end{array}$ & $\begin{array}{c}0.0691 \\
{[0.0595]}\end{array}$ & 938 \\
\hline Discusses politics with: & & & & & & & & & & & \\
\hline Parents & $\begin{array}{c}0.0515 \\
{[0.1004]}\end{array}$ & $\begin{array}{c}0.0470 \\
{[0.0732]}\end{array}$ & 3,005 & $\begin{array}{c}0.0550 \\
{[0.1048]}\end{array}$ & 1,392 & $\begin{array}{c}0.0931 \\
{[0.1401]}\end{array}$ & 747 & $\begin{array}{c}0.0427 \\
{[0.0733]}\end{array}$ & $\begin{array}{c}0.0547 \\
{[0.0840]}\end{array}$ & $\begin{array}{c}0.0981 \\
{[0.1014]}\end{array}$ & 2,786 \\
\hline Friends & $\begin{array}{c}0.1295 \\
{[0.1012]}\end{array}$ & $\begin{array}{c}0.0776 \\
{[0.0720]}\end{array}$ & 3,017 & $\begin{array}{c}0.1048 \\
{[0.1050]}\end{array}$ & 1,399 & $\begin{array}{c}0.0560 \\
{[0.1447]}\end{array}$ & 749 & $\begin{array}{c}0.0954 \\
{[0.0734]}\end{array}$ & $\begin{array}{c}0.1050 \\
{[0.0836]}\end{array}$ & $\begin{array}{c}0.0969 \\
{[0.1004]}\end{array}$ & 2,808 \\
\hline Frequency of following politics in: & & & & & & & & & & & \\
\hline Newspapers or magazines & $\begin{array}{c}-0.0224 \\
{[0.1994]}\end{array}$ & $\begin{array}{c}-0.0803 \\
{[0.1461]}\end{array}$ & 2,961 & $\begin{array}{c}0.0074 \\
{[0.2043]}\end{array}$ & 1,365 & $\begin{array}{c}-0.0671 \\
{[0.2815]}\end{array}$ & 733 & $\begin{array}{c}-0.0342 \\
{[0.1470]}\end{array}$ & $\begin{array}{c}-0.0651 \\
{[0.1683]}\end{array}$ & $\begin{array}{c}-0.1495 \\
{[0.2035]}\end{array}$ & 2,700 \\
\hline TV news & $\begin{array}{c}0.1791 \\
{[0.2099]}\end{array}$ & $\begin{array}{c}-0.1524 \\
{[0.1533]}\end{array}$ & 2,990 & $\begin{array}{c}0.2677 \\
{[0.2150]}\end{array}$ & 1,385 & $\begin{array}{c}0.4887 \\
{[0.2911]^{*}}\end{array}$ & 740 & $\begin{array}{c}0.0858 \\
{[0.1503]}\end{array}$ & $\begin{array}{c}0.2079 \\
{[0.1724]}\end{array}$ & $\begin{array}{c}0.3443 \\
{[0.2103]}\end{array}$ & 2,758 \\
\hline Internet & $\begin{array}{c}0.2547 \\
{[0.2341]}\end{array}$ & $\begin{array}{c}0.2016 \\
{[0.1693]}\end{array}$ & 2,967 & $\begin{array}{c}0.3229 \\
{[0.2400]}\end{array}$ & 1,374 & $\begin{array}{c}0.4932 \\
{[0.3336]}\end{array}$ & 735 & $\begin{array}{c}0.2331 \\
{[0.1715]}\end{array}$ & $\begin{array}{c}0.2654 \\
{[0.1961]}\end{array}$ & $\begin{array}{c}0.3819 \\
{[0.2375]}\end{array}$ & 2,712 \\
\hline TV campaign & $\begin{array}{c}0.7799 \\
{[0.6351]}\end{array}$ & $\begin{array}{c}-0.3525 \\
{[0.4475]}\end{array}$ & 2,918 & $\begin{array}{c}0.7250 \\
{[0.6463]}\end{array}$ & 1,351 & $\begin{array}{l}1.1716 \\
0.8942\end{array}$ & 719 & $\begin{array}{c}0.3461 \\
{[0.4652]}\end{array}$ & $\begin{array}{c}0.6494 \\
{[0.5357]}\end{array}$ & $\begin{array}{c}1.1563 \\
{[0.6498]^{*}}\end{array}$ & 2,612 \\
\hline Presidential debates & $\begin{array}{c}0.1073 \\
{[0.1296]}\end{array}$ & $\begin{array}{c}-0.0465 \\
{[0.0930]}\end{array}$ & 2,979 & $\begin{array}{c}0.1458 \\
{[0.1354]}\end{array}$ & 1,380 & $\begin{array}{c}0.2174 \\
{[0.1742]}\end{array}$ & 737 & $\begin{array}{c}0.0393 \\
{[0.0977]}\end{array}$ & $\begin{array}{c}0.0724 \\
{[0.1109]}\end{array}$ & $\begin{array}{c}0.1246 \\
{[0.1334]}\end{array}$ & 2,736 \\
\hline Vote participation & $\begin{array}{c}0.1859 \\
{[0.0441]^{* * *}}\end{array}$ & $\begin{array}{c}0.2694 \\
{[0.0320]^{* * *}}\end{array}$ & 3,013 & $\begin{array}{c}0.1854 \\
{[0.0460]^{* * *}}\end{array}$ & 1,397 & $\begin{array}{c}0.1414 \\
{[0.0637]^{* *}}\end{array}$ & 747 & $\begin{array}{c}0.1554 \\
{[0.0323]^{* * *}}\end{array}$ & $\begin{array}{c}0.1463 \\
{[0.0376]^{* *}}\end{array}$ & $\begin{array}{c}0.1465 \\
{[0.0466]^{* *}}\end{array}$ & 2,800 \\
\hline $\begin{array}{l}\text { Extra Knowledge Variables } \\
\text { \% Correct Answers on Questions concerning: }\end{array}$ & & & & & & & & & & & \\
\hline Candidates' party affiliation & $\begin{array}{c}0.0144 \\
{[0.0188]}\end{array}$ & $\begin{array}{c}0.0012 \\
{[0.0135]}\end{array}$ & 3,019 & $\begin{array}{c}0.0057 \\
{[0.0192]}\end{array}$ & 1,399 & $\begin{array}{c}0.0092 \\
{[0.0272]}\end{array}$ & 749 & $\begin{array}{r}0.0107 \\
{[0.0137]}\end{array}$ & $\begin{array}{r}0.0122 \\
{[0.0157]}\end{array}$ & $\begin{array}{c}0.0160 \\
{[0.0188]}\end{array}$ & 2,802 \\
\hline Candidates' Policies & $\begin{array}{c}-0.0227 \\
{[0.0242]}\end{array}$ & $\begin{array}{c}-0.0095 \\
{[0.0175]}\end{array}$ & 3,019 & $\begin{array}{c}-0.0157 \\
{[0.0248]}\end{array}$ & 1,399 & $\begin{array}{c}-0.0554 \\
{[0.0341]}\end{array}$ & 749 & $\begin{array}{r}-0.0117 \\
{[0.0181]}\end{array}$ & $\begin{array}{r}-0.0118 \\
{[0.0206]}\end{array}$ & $\begin{array}{c}-0.0238 \\
{[0.0248]}\end{array}$ & 2,802 \\
\hline Identified the most right-wing party & $\begin{array}{c}0.0232 \\
{[0.0464]}\end{array}$ & $\begin{array}{c}0.0560 \\
{[0.0330]^{*}}\end{array}$ & 3,019 & $\begin{array}{c}0.0237 \\
{[0.0478]}\end{array}$ & 1,399 & $\begin{array}{c}-0.0459 \\
{[0.0667]}\end{array}$ & 749 & $\begin{array}{r}0.0267 \\
{[0.0326]}\end{array}$ & $\begin{array}{r}0.0215 \\
{[0.0374]}\end{array}$ & $\begin{array}{l}-0.0032 \\
{[0.0455]}\end{array}$ & 2,802 \\
\hline Sample (in age) & {$[16.75,19.25]$} & {$[16.75,19.25]$} & & {$[17.5,18.5]$} & & {$[17.75,18.25]$} & & {$[16.75,19.25]$} & {$[16.75,19.25]$} & {$[16.75,19.25]$} & \\
\hline
\end{tabular}

Notes: Entries in columns 1-4 represent OLS regression results including age polynomial controls fully interacted with a dummy for age 18 or older, school fixed effects and indicators for whether the respondent voted before,

mother education, race and gender. Huber White standard errors are in brackets. Entries in columns 5-7 report estimates for differences at the boundary points of two local linear regressions using a rectangular kernel. Standard errors are calculated using the formula in Porter (2003). *** significant at the 1 percent level, ** significant at the 5 percent level, * significant at the 10 percent level. 
Table A6 - Description of Variables

DEMOGRAPHICS AND SOCIO-ECONOMIC VARIABLES

Indicar for wherer the respondent declo

Female $\quad$ Indicator for whether the respondent declares to be female.

Mother has college education Indicator for whether the respondent declares his/her mother to have some college education or more.

Live with parent(s)_ Indicator for whether the respondent declares to live with at least one parent

Work

Indicator for whether the respondent declares to be in employment

Responded seriously to the survey

Responded seriously to the sun to apply to college
Plat

Frequency of church attendance

Indicator for whether the respondent declares to be in employment
Indicator for whether the respondent declares to have voted before the 20

Indicator for whether the respondent declares to have voted before the 2010 Election

Indicator for whether the respondent declares to have answered seriously to the survey

Indicator for whether the respondent declares to plan to apply for college.

Mother has a party preference

Number of days per month respondent declares to attend church

Universidade de São Paulo

Indicator for whether the respondent declares hisher mother prefers a political party.

Indicator for whether the respondent was surveyed at USP

Anglo Vestibulares

Indicator for whether the respondent was surveyed at an "Anglo Vestibulares" school

Public High School

Indicator for whether the respondent was surveyed at a public high school

\section{OUTCOMES}

Voted in the 2010 Election

$\%$ Correct answers in the political quiz

Indicator for whether the respondent declared to have voted in the 2010 Election

Proportion of correct answers in the entire political knowledge quiz (questions 1-14)

Proportion of correct answers to questions concerning candidates' parties (questions 4-9)

$\%$ Correct answers in questions concerning parties

$\%$ Correct answers in questions concerning policies

Identified the most right-wing party

Proportion of correct answers to questions concerning candidates' policies (questions 1-3 and 10-13)

Indicator for whether the respondent answered correctly who most right-wing party among two options (question 14)

Always reads political section of newspapers

Indicator for whether the respondent declares to always read the politics section in newspapers

Frequency of following politics in:

Newspapers or magazines

TV news

Internet

TV political campaigns

Presidential debates

Number of days per week respondent declares to consume political information from TV news

Number of TV political campaigns watched during the 2010 electoral seaso

Number of presidential debates watched during the 2010 electoral seaso

Discusses politics with:

Parents

This is based on a multiple-choice question on the frequency of discussion about politics with parents.

The options were: (a) never; (b) rarely; (c) often; (d) very often.

The answers were ranked in a 4 point scale, ranging from (a) to (d), and normalized to have mean zero and standard deviation one.

Friends

This is based on a multiple-choice question on the frequency of discussion about politics with parents.

The options were: (a) never; (b) rarely; (c) often; (d) very often.

The answers were ranked in a 4 point scale, ranging from (a) to (d), and normalized to have mean zero and standard deviation one. 


\section{A7- Political Quiz}

1. Cite a political position held by Dilma Rousseff before running for President in the 2010 Election.

2. Cite a political position held by Marina Silva before running for President in the 2010 Election.

3. Cite a political position held by Jose Serra before running for President in the 2010 Election.

4. What is the political party affiliation of Dilma Rousseff?

5. What is the political party affiliation of Dilma Rousseff's running mate?

6. What is the political party affiliation of Marina Silva?

7. What is the political party affiliation of Marina Silva's running mate?

8. What is the political party affiliation of Jose Serra?

9. What is the political party affiliation of Jose Serra's running mate?

10. Which candidate was partly responsible for the introduction of generic drugs?
( ) I do not know
( ) Dilma Rousseff
( ) Marina Silva
( ) Jose Serra
( ) Other/None

11. Which candidate was partly responsible for the implementation of the $\mathrm{PAC}^{1}$ ?

( ) I do not know

( ) Dilma Rousseff

( ) Marina Silva

( ) Jose Serra

( ) Other/None

12. Which candidate was partly responsible for the increase in the basic interest rate (SELIC)?

( ) I do not know

( ) Dilma Rousseff

( ) Marina Silva

( ) Jose Serra

( ) Other/None

13. Which candidate was partly responsible for the creation of protected areas in the Amazon region?

( ) I do not know

( ) Dilma Rousseff

( ) Marina Silva

( ) Jose Serra

( ) Other/None

14. Which of these parties is more right-wing oriented?
( ) DEM
( ) PSOL

\footnotetext{
${ }^{1}$ Programa de Aceleração do Crescimento (PAC) refers to the growth acceleration program.
} 